\title{
Enhanced sensitivity to cisplatin and gemcitabine in Brca1-deficient murine mammary epithelial cells
}

\author{
Elizabeth Alli ${ }^{1}$, Vandana B Sharma ${ }^{1}$, Anne-Renee Hartman', Patrick S Lin ${ }^{1}$, Lisa McPherson ${ }^{1}$ and James M Ford ${ }^{1,2^{*}}$
}

\begin{abstract}
Background: Breast cancers due to germline mutations or altered expression of the BRCA1 gene associate with an aggressive clinical course and frequently exhibit a "triple-negative" phenotype, i.e. lack of expression of the estrogen and progesterone hormone receptors and lack of overexpression of the HER2/NEU oncogene, thereby rendering them relatively insensitive to hormonal manipulation and targeted HER2 therapy, respectively. BRCA1 plays a role in multiple DNA repair pathways, and thus, when mutated, results in sensitivity to certain DNA damaging drugs.

Results: Here, we used a Brcal murine mammary epithelial cell (MMEC) model to examine the effect of loss of Brca1 on cellular sensitivity to various chemotherapy drugs. To explore novel therapeutic strategies, we included DNA damaging and non-DNA damaging drugs whose mechanisms are dependent and independent of DNA repair, respectively, and drugs that are used in standard and non-standard lines of therapy for breast cancer. To understand the cellular mechanism, we also determined the role that DNA repair plays in sensitivity to these drugs. We found that cisplatin and gemcitabine had the greatest specific therapeutic benefit to Brcal-deficient MMECs, and that when used in combination produced a synergistic effect. This sensitivity may be attributed in part to defective NER, which is one of the DNA repair pathways normally responsible for repairing DNA adducts produced by cisplatin and is shown in this study to be defective in Brca1-deficient MMECs. Brca1-deficient MMECs were not differentially sensitive to the standard breast cancer chemotherapy drugs doxorubicin, docetaxel or 5-FU.
\end{abstract}

Conclusions: Both cisplatin and gemcitabine should be explored in clinical trials for first line regimens for BRCA1associated and triple-negative breast cancer.

\section{Background}

Inheritance of a mutation in the $B R C A 1$ gene confers a $45-65 \%$ average lifetime risk for developing breast cancer and an increased risk for developing ovarian cancer [1]. While germline mutations in BRCA1 account for 5\% of breast cancer cases, evidence suggests that epigenetic silencing of $B R C A 1$ by promoter hypermethylation and other mechanisms may contribute to up to $30 \%$ of sporadic breast cancers [2-7]. BRCA1-associated breast cancers have a characteristic phenotype; in general, these tumors have a high mitotic index, contain p53 mutations, and often exhibit a triple-negative phenotype

\footnotetext{
* Correspondence: jmf@stanford.edu

1 Department of Medicine, Division of Oncology, Stanford University School of Medicine, Center for Clinical Sciences Research, Stanford, CA 94305, USA Full list of author information is available at the end of the article
}

(i.e. lack of expression of estrogen and progesterone receptors and lack of overexpression of the HER2/NEU oncogene) $[8,9]$. This triple-negative status renders BRCA1-associated cancers insensitive to hormonal manipulation or targeted therapy with trastuzumab, respectively. With the exception of PARP inhibitors, an investigational therapeutic strategy for BRCA-deficient cancers [10], empirically chosen cytotoxic chemotherapy is the primary option for treating patients with BRCA1associated and triple-negative breast cancer.

BRCA1 plays multiple roles in DNA damage response pathways. BRCA1 has a well-established role in DNA double-strand break repair [11]. More recently our lab has shown that BRCA1 is involved in DNA base-excision repair (BER) [12] and nucleotide-excision repair (NER) $[13,14]$. BER repairs single base-pair lesions that

\section{Biomed Central}


are typically induced by endogenous agents, such as oxidative byproducts of normal cellular metabolism. NER functions to repair bulky lesions or DNA adducts induced by exogenous means such as ultraviolet (UV)irradiation, carcinogens including polyaromatic hydrocarbons and tobacco, and certain chemotherapy agents such as cisplatin. NER can be subdivided into two genetically distinct subpathways: global genomic repair (GGR) that removes lesions from the whole genome and transcription-coupled repair (TCR) that removes lesions from actively transcribed DNA. We have shown in human tumor cells that BRCA1 directly affects the GGR subpathway of NER, and that this function may occur through transcriptional regulation of NER genes involved in the recognition of adducts in genomic DNA, including XPC and DDB2 (the genes mutated in xeroderma pigmentosum complementation groups $\mathrm{C}$ and $\mathrm{E}$, respectively) [13].

Cellular characteristics that contribute to carcinogenesis, such as defects found in DNA repair pathways, may be exploited for cancer therapy. For example, cancer cells deficient in BRCA1 tend to exhibit defective DNA repair, and in turn, are sensitive to drugs such as mitomycin $\mathrm{C}$ and cisplatin, which induce intrastrand and interstrand DNA crosslinks, stalled replication forks, and DNA double-strand breaks [15-20], and PARP inhibitors, which through a synthetic lethal mechanism further inhibit DNA repair mechanisms and promote cytotoxicity [21,22].

Here, we used an isogenic Brcal murine mammary epithelial cell (MMEC) model to examine the specific effect of loss of Brca1 on cellular sensitivity to various chemotherapeutic agents in a manner beyond that achievable in less well-characterized human tumor cell lines. We included DNA damaging and non-DNA damaging drugs whose mechanisms are dependent and independent of DNA repair, respectively, and drugs that are used in standard and non-standard lines of therapy for breast cancer.

\section{Methods}

\section{Cell Lines}

$\mathrm{Brcal}^{+/+}$and $\mathrm{BrCa1}^{-/-}$MMECs were kindly provided by the laboratory of Kenneth $\mathrm{H}$. Cowan (Eppley Institute for Research in Cancer and Allied Diseases, University of Nebraska Medical Center) and were cultured as previously described [23]. MMECs were isolated from Brcal $1^{\mathrm{f} / \mathrm{fl}}$ mice [24]. These mice carry loxP sites flanking exon 11 of the Brca1 gene and develop normally. Brca $1^{\mathrm{fl} / \mathrm{fl}}$ MMECs were infected with an HPV-16E6 (Neo $\left.{ }^{+}\right)$retrovirus to inhibit p53 function and immortalize the cells. Brca1 $1^{-1-}$ MMECs were generated by deleting exon 11 of Brca1 following transfection with pBabe-Cre (Puro ${ }^{+}$) retrovirus.

\section{Real-time RT-PCR (RT-qPCR)}

Total RNA was isolated and purified using RNeasy Protect Mini Kit (Qiagen) with the following modifications. Cells were homogenized using the QIAshredder column (Qiagen) and the resulting lysates treated with RNaseFree DNase (Qiagen) to remove genomic DNA. Total RNA $(2.5 \mu \mathrm{g})$ from each sample was reverse transcribed using SuperScript ${ }^{\mathrm{TM}}$ III First-Strand Synthesis System (Invitrogen) to create cDNA libraries. The Platinum ${ }^{\circledR}$ SYBR $^{\circledR}$ Green qPCR SuperMix-UDG (Invitrogen) was used for PCR of cDNA samples in a protocol consisting of 50 cycles of denaturation $\left(95^{\circ} \mathrm{C}\right.$ for $\left.15 \mathrm{sec}\right)$, primer annealing $\left(57^{\circ} \mathrm{C}\right.$ for $\left.30 \mathrm{sec}\right)$, and primer extension $\left(72^{\circ} \mathrm{C}\right.$ for $30 \mathrm{sec}$ ) using an ABI PRISM 7900 Sequence Detection System (Applied Biosystems). For calibration and generation of standard curves, we used cDNA from mouse embryo fibroblasts as reference standards [25]. All reactions were carried out in triplicate with minimal $\mathrm{Ct}$ variability seen. The transcript level of each gene was normalized to that of Gapdh and expressed as fold induction over 0 -hour reference level to examine UV damage-inducible transcripts and over untreated control to examine drug-inducible transcripts. The mouse $D d b 2$ primers used were 5'-GCCGATACCCAGATCCTA ATCTT-3' and 5'-ACACATCATCTTCCCTGAGCTTC3'. The mouse $X p c$ primers used were 5'-ATCATTCCA ATTCGCTTTACCAA-3' and 5'-GTTCCGATGAAC CACTTTACCAG-3'. The mouse Xpa primers used were 5'-CACCAAAGGTGGCTTCATTTTAG-3' and 5'TGGTGTAATCAAACTCCATGACG-3'. The mouse Gapdh primers used were 5'-GGAGAAACCTGC CAAGTATGATG-3' and 5'GACAACCTGGTCCTC AGTGTAGC-3'.

\section{GGR Assay}

Repair of DNA adducts, cyclobutane pyrimidine dimers (CPDs) and 6-4 photoproducts (6-4PPs), from total genomic DNA at different times following UV-irradiation was measured using an immunoslot blot assay as previously described [13,26]. To control for replication, ${ }^{3} \mathrm{H}$-thymidine labeled cells were used. Monoclonal antibodies specific for either CPDs (1:1000) or 6-4PPs (1:500) were kindly supplied by Toshio Mori (Nara Medical University, Japan). Genomic DNA from unirradiated cells was loaded as a control for nonspecific antibody binding. Data from triplicate DNA samples from three different biological experiments were averaged and normalized to the unrepaired damaged control (i.e. $\mathrm{UV}=10 \mathrm{~J} / \mathrm{m}^{2}$, Time $=0$ ). Statistical analysis of differences in DNA repair curves due to expression of Brcal were performed using the unpaired T-test.

\section{TCR Assay}

To determine the rate of removal of adducts from the transcribed strand of a specific gene fragment, strand- 
specific RNA probes were used to evaluate the frequency of $\mathrm{CPDs}$ in a 14-kb Bam $\mathrm{H} 1$ restriction fragment spanning the central region of the mouse Dhfr gene, as previously described $[27,28]$. Cells were irradiated with $10 \mathrm{~J} / \mathrm{m}^{2}$ of UV-C, lysed immediately for an initial sample (time $=0$ ), or incubated for up to 24 hrs to allow lesion repair. The frequency of induction and rate of removal of CPDs from the transcribed strand and non-transcribed strand of the Dhfr gene was measured by treating purified BamHI-digested DNA with bacteriophage T4 endonuclease V (generously supplied by R. Stephen Lloyd, Oregon Health Sciences University), and then quantifying the reappearance of the full-length restriction fragments in DNA from cells allowed various times to remove the lesions using denaturing electrophoresis and Southern blotting.

\section{Cell Sensitivity Assays}

For UV sensitivity, cells were plated in 96 well plates at a density of $10^{3}$ cells/well in triplicate and allowed to attach overnight. Cells were then washed with PBS, exposed to UV-C irradiation at doses of $0,5,10,20$, and $30 \mathrm{~J} / \mathrm{m}^{2}$, and allowed to recover for 48 hours. For drug sensitivity, cells were plated in triplicate and allowed to attach overnight. Cells were treated with increasing concentrations of doxorubicin, 5-FU, or paclitaxel for 48 hours, or cisplatin (Sigma-Aldrich), carboplatin, oxaliplatin, or gemcitabine for 72 hours. Drugs were provided by the Stanford Cancer Center unless otherwise indicated. Incubation times were determined to be the shortest number of 24 hour periods that produced a full dose-response curve and were carried out at $37^{\circ} \mathrm{C}$ and $5 \% \mathrm{CO}_{2}$. Media was then removed and replaced with fresh media containing $1 \mathrm{mg} / \mathrm{ml}$ 3-(4,5-dimethylthiazol2-yl)-2,5-diphenyltetrazolium bromide (MTT) solution until formation of formazan crystals ( $\sim 3$ hours). The MTT formazan crystals were dissolved in DMSO (200 $\mu \mathrm{l} /$ well) and glycine buffer ( $25 \mu \mathrm{l} /$ well $)$. Absorbance was measured at $570 \mathrm{~nm}$ with a VERSAmax microplate reader (Molecular Devices) and a logarithmic plot of absorbance versus UV dose or drug concentration recorded. Cell viability was expressed as the ratio of the treated cells to that of the untreated controls at each dose or concentration. The $\mathrm{IC}_{50}$ value for each cell line was determined using SoftMax ${ }^{\circledR}$ Pro software (Molecular Devices) and statistical significance calculated by students $\mathrm{t}$-test using the average $\mathrm{IC}_{50}$ values from multiple independent experiments.

\section{Combination Treatment}

Cells were treated with cisplatin and gemcitabine alone and in various dose combinations for 48 hours and then subjected to the MTT assay described above. Isobologram analysis differentiated between antagonism, synergism, and additive effects as previously described [29]. Combination index was determined as described by Chou and Talalay [30].

\section{Alkaline Comet Assay}

At 24 hours following treatment with drug, cells were subjected to the alkaline comet assay for the detection of DNA strand breaks as previously described [31]. Briefly, cells were embedded at low density onto comet slides, lysed, exposed to alkaline conditions to denature DNA, and subjected to electrophoresis. DNA was stained with $\mathrm{SYBR}^{\circledR}$ green and visualized by fluorescent microscopy as a comet in shape. The percentage of DNA in the comet tails, i.e. DNA damage, was calculated using CometScore software (TriTek Corporation).

\section{Results}

Characterization of the Cellular System

BRCA1-associated cancers, including hereditary breast cancers due to germline mutations and sporadic breast cancers associated with promoter hypermethylation, have reduced or complete loss of expression of BRCA1 protein, and are frequently accompanied by mutations in TP53 $[2,8,32,33]$. Therefore, to study the effect of loss of BRCA1 expression on chemosensitivity to DNA repair- dependent and independent drugs, we used $\mathrm{Brcal}^{+/+}$and $\mathrm{Brca1}^{-/-}$MMECs that were generated by disrupting the Brcal gene in MMECs immortalized and p53-inactivated by infection with HPV-16E6. These cells have previously been shown to have undergone homozygous deletion of Brcal exon 11 and to have lost expression by RT-PCR, Northern and Western blotting [23]. RT-PCR confirmed the expression and loss of expression of Brcal in $\mathrm{BrCa1}^{+/+}$and $\mathrm{BrCa1}^{-/-}$MMECs, respectively (data not shown). The $\mathrm{Brca1}^{-/-}$MMECs have also been reported to harbor defective DNA base-excision repair [12] as well as increased genetic instability [34] compared to $\mathrm{Brca1}^{+/+}$MMECs, which is typical of BRCA1-mutant breast cancer cells. Furthermore, the $\mathrm{BrCal}^{+/+}$and $\mathrm{BrCa1}^{-/-}$MMECs showed similar proliferation rates (data not shown), which allowed for direct comparison of sensitivity to various drugs.

\section{Effect of Loss of Brca1 on Sensitivity to DNA Damaging Agents}

We examined the effect of loss of Brcal on sensitivity to DNA damaging agents, including doxorubicin, cisplatin, carboplatin, and oxaliplatin. Doxorubicin is an anthracycline that inhibits topoisomerase II and thereby produces DNA double-strand breaks; it is commonly used in the treatment of breast cancer. Cisplatin, carboplatin, and oxaliplatin are platinum agents, which induce intraand inter-strand DNA crosslinks that are typically repaired by NER, or when left unrepaired, convert to 
DNA double-strand breaks. Following treatment with increasing concentrations of each drug, $\mathrm{BrCal}^{+/+}$and Brca1 $^{-1-}$ MMECs were analyzed for sensitivity by MTT assay. $\mathrm{BrCa1}^{+/+}$and $\mathrm{BrCa1}^{-1-}$ MMECs were similarly sensitive to doxorubicin (Figure 1a and Table 1; p =0.3). However, Brca1 ${ }^{-1-}$ MMECs were more sensitive than Brca1 ${ }^{+/+}$MMECs to all of the platinum agents (Figure $1 \mathrm{~b}-\mathrm{d}$ and Table 1), with the greatest difference being observed for cisplatin. Specifically, loss of Brca1 associated with a 13 -fold increase in sensitivity to cisplatin (Figure 1b; $\mathrm{p}=0.001$ ).

\section{Effect of Loss of Brca1 on Sensitivity to Non-DNA Damaging Agents}

We next examined the effect of loss of Brcal on sensitivity to non-DNA damaging drugs thought to be
Table 1 IC $_{50}$ Values for Chemotherapy Drugs

\begin{tabular}{lccl}
\hline & Brca $^{+/+}$MMECs & Brca1 $^{-/-}$MMECs & p-value \\
\hline DNA-damaging Drugs & $(\mu \mathrm{M})$ & $(\mu \mathrm{M})$ & \\
\hline Doxorubicin & $0.06 \pm 0.02$ & $0.04 \pm 0.02$ & 0.3 \\
\hline Cisplatin & $0.8 \pm 0.1$ & $0.06 \pm 0.02$ & $0.001^{* *}$ \\
\hline Carboplatin & $10 \pm 4$ & $6 \pm 2$ & $0.03^{*}$ \\
\hline Oxaliplatin & $5 \pm 1$ & $2 \pm 1$ & $0.04^{*}$ \\
\hline Taxanes & & & \\
\hline Paclitaxel & $0.4 \pm 0.3$ & $0.08 \pm 0.06$ & 0.1 \\
\hline Docetaxel & $0.001 \pm 0.0009$ & $0.002 \pm 0.002$ & 0.5 \\
\hline Antimetabolites & & & \\
\hline 5-FU & $0.8 \pm 0.5$ & $4 \pm 0.9$ & $0.004^{* *}$ \\
\hline Gemcitabine & $0.05 \pm 0.02$ & $0.002 \pm 0$. & $0.02^{*}$
\end{tabular}

**Highly statistically significant $(p<0.01)$

*Statistically significant $(p<0.05)$

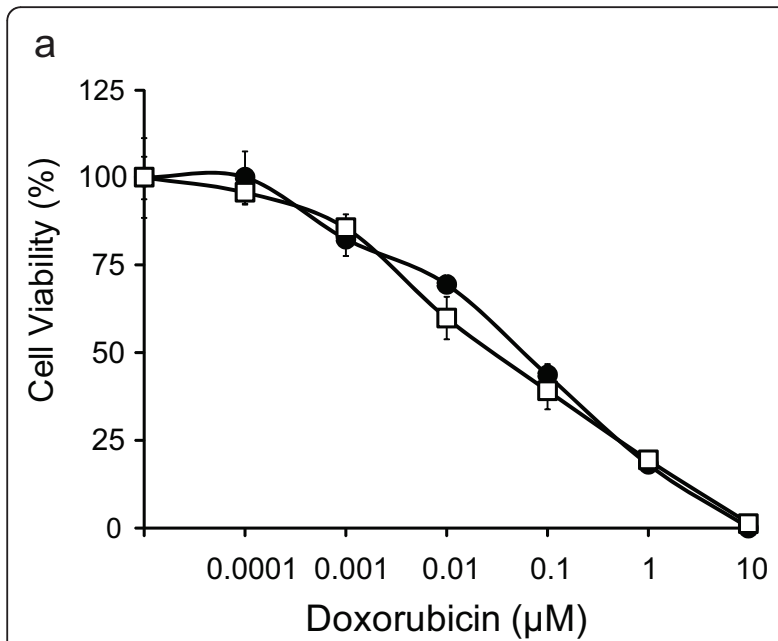

C

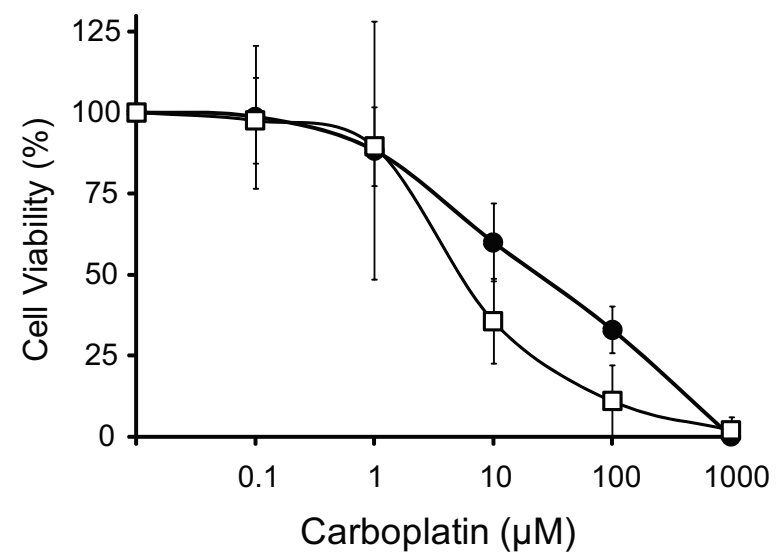

b

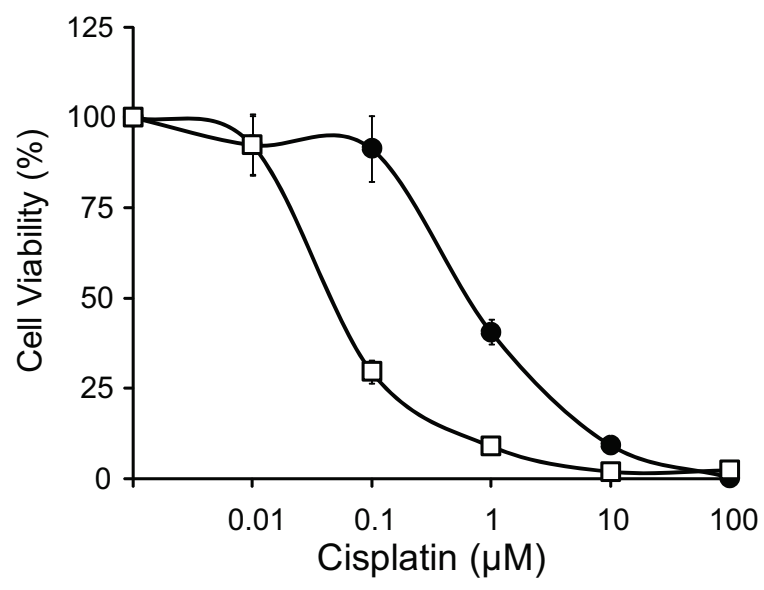

d

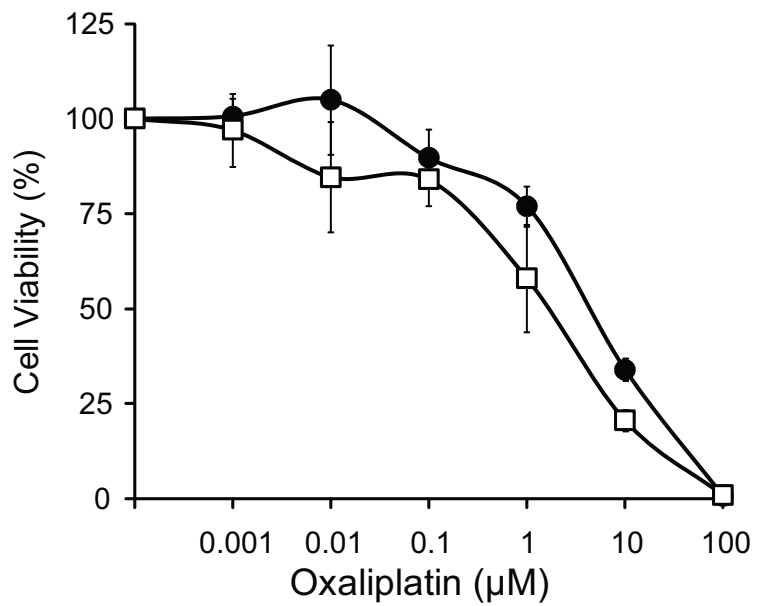

Figure 1 Effect of BRCA1-deficiency on Sensitivity to DNA Damaging Agents. Brca ${ }^{+/+}$(black circle) and Brca $1^{-/-}$(white square) cells were analyzed for cellular sensitivity to (a) doxorubicin (b) cisplatin (c) carboplatin or (d) oxaliplatin by MTT assay. Each data point represents the average of triplicate readings \pm S.D. Graphs are representative of at least three independent experiments. 
independent of DNA repair function. $\mathrm{BrCa}^{+/+}$and $\mathrm{BrCa}^{-1-}$ MMECs were treated with increasing concentrations of taxanes (paclitaxel or docetaxel) or antimetabolites (5-FU or gemcitabine), and evaluated for cellular sensitivity by MTT assay. We found that $\mathrm{Brcal}^{+/+}$and $\mathrm{Brcal}^{-1-}$ MMECs were similarly sensitive to both paclitaxel (Figure 2a; $\mathrm{p}=0.1$ ) and docetaxel (Figure 2b; $\mathrm{p}=$ $0.5)$. Sensitivity to the antimetabolites, on the other hand, produced contrasting results. Compared to Brcal ${ }^{+/+}$MMECs, $\mathrm{Brcal}^{-/-}$MMECs were 5-fold less sensitive to 5 -FU (Figure 2c; $\mathrm{p}=0.004$ ), but 27 -fold more sensitive to gemcitabine (Figure $2 \mathrm{~d} ; \mathrm{p}=0.02$ ). Table 1 summarizes these data. Interestingly, loss of Brcal associated with cellular sensitivity to gemcitabine, which unlike the taxanes and 5-FU, is not currently used among standard first lines of therapy for breast cancer.
Combination Therapy in $\mathrm{Brca}^{+/+}$and $\mathrm{Brca1}^{-/-}$MMECs

Our data has indicated that loss of Brcal produced the greatest sensitivity to cisplatin (Figure $1 \mathrm{~b}$ ) and to gemcitabine (Figure 2d). Therefore, we next assessed the effect of these drugs used in combination by isobologram analysis and found that there was a synergistic effect between cisplatin and gemcitabine in both $\mathrm{Brcal}^{+/+}$and $\mathrm{Brcal}^{-/-}$MMECs, but that the concentrations required to produce the synergistic effect in $\mathrm{Brcal}^{-1-}$ MMECs were much lower than those needed for $\mathrm{BrCa1}^{+/+}$MMECs (Figure 3). The combination index (CI) for $\mathrm{BrCaI}^{+/+}$and $\mathrm{BrCa}^{-/-}$MMECs were 0.01 and 0.05 , respectively, where $\mathrm{CI}<1$ is synergism, $\mathrm{CI}=$ 1 is additive, and CI $>1$ is antagonism. Therefore, these data confirmed synergism between cisplatin and gemcitabine.
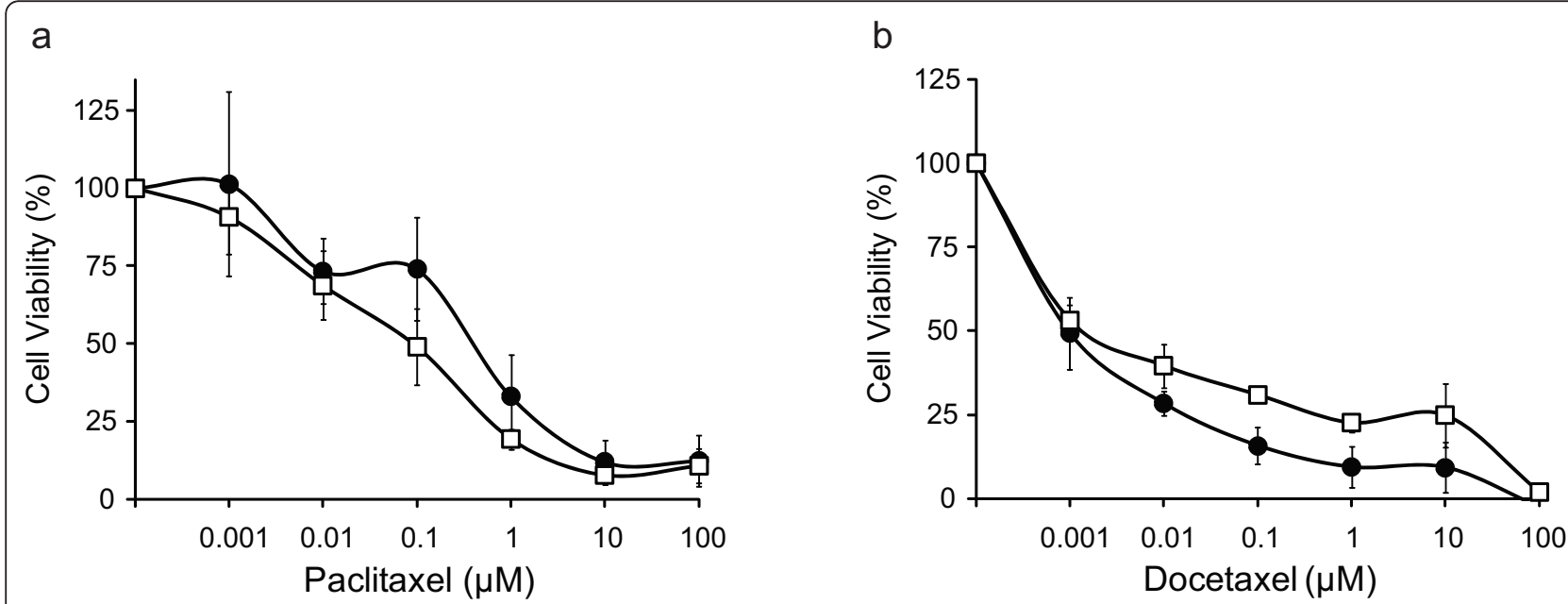

C

d
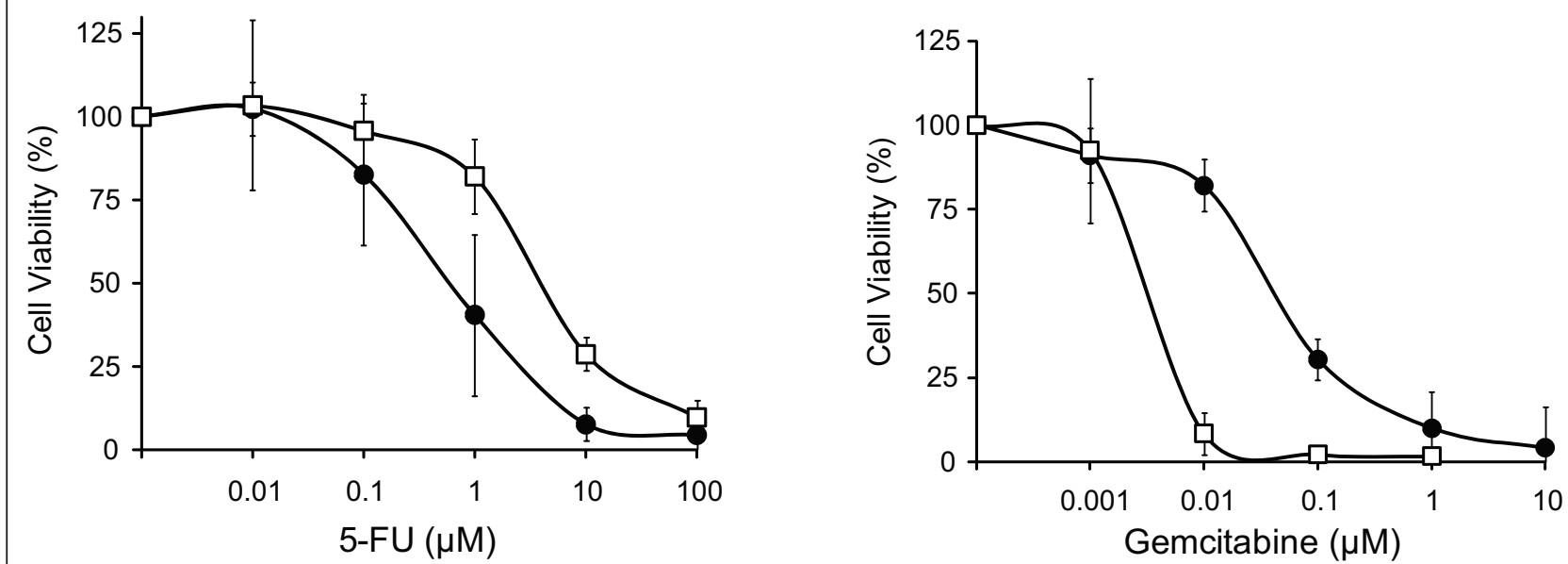

Figure 2 Effect of Brca1-deficiency on Sensitivity to Non-DNA Damaging Agents. Brca1 ${ }^{+/+}$(black circle) and Brca1 ${ }^{-/-}$(white square) cells were analyzed for cellular sensitivity to taxanes, paclitaxel (a) or docetaxel (b), and to antimetabolites, 5-FU (c) or gemcitabine (d) by MTT assay. Each data point represents the average of triplicate readings \pm S.D. Graphs are representative of at least three independent experiments. 
a

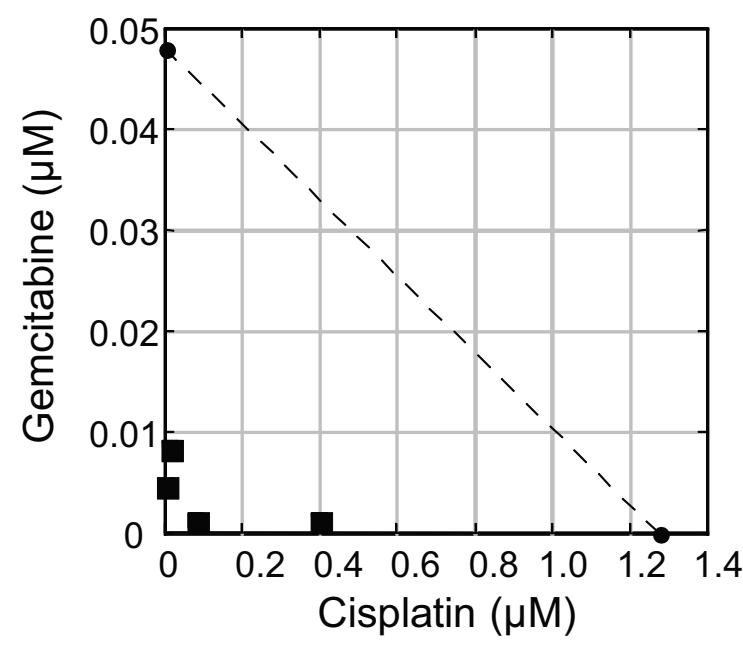

b

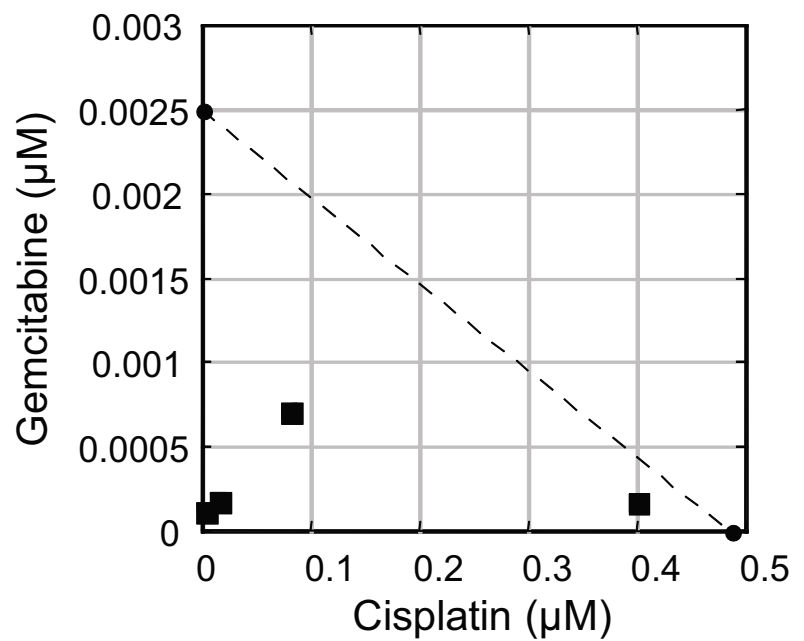

Figure 3 Sensitivity to the Combination of Cisplatin and Gemcitabine. Brca1 ${ }^{+/+}$(a) and Brca1 ${ }^{-/-}$(b) MMECs were treated with cisplatin and gemcitabine either alone or in combination and analyzed for sensitivity by MTT assay. The $\mathrm{IC}_{50}$ values determined from treatment with cisplatin and gemcitabine alone were plotted as axial points (black circles) on a Cartesian plot to generate a line of additivity. The $\mathbf{C}_{50}$ values for each combination of cisplatin and gemcitabine were then plotted as data points (black squares). Data points above the line of additivity represent an antagonistic effect, data points on the line of additivity represent an additive effect, and data points below the line additivity represent a synergistic effect. Data are representative of at least three independent experiments.

\section{Effect of Loss of Brca1 on NER}

Given that cisplatin produces lesions that are repaired by NER, we next examined the functionality of the NER pathway in $\mathrm{BrCa1}^{+/+}$and Brca1 $1^{-/}$MMECs. Using an assay for GGR that measures the removal of UVinduced DNA lesions (CPDs and 6-4PPs), we found that repair of CPDs $24 \mathrm{hrs}$ after UV irradiation decreased from $22 \pm 2 \%$ in Brcal $^{+/+}$MMECs to $12 \pm 2 \%$ in Brca1 $^{-/-}$MMECs (Figure 4a; $\mathrm{p}=0.025$ ). No difference was observed for 6-4PPs; both cell lines repaired nearly $100 \%$ of these adducts by 24 hrs (data not shown). Analysis of TCR showed no difference between $\mathrm{BrCa}^{+/+}$ and $\mathrm{Brca1}^{-/-}$MMECs with greater than $70 \%$ repair of CPDs in the transcribed strand of the mouse $d h f r$ gene being observed at 24 hours (data not shown).

To investigate the biological consequence of the different abilities in GGR between $\mathrm{BrCa}^{+/+}$and $\mathrm{BrCa1}^{-1-}$ MMECs, we examined cell survival after UV irradiation. As shown in Figure $4 \mathrm{~b}$, cell viability decreased in a dose-response manner in both $\mathrm{BrCa1}^{+/+}$and $\mathrm{BrCa1}^{-1-}$ MMECs following exposure to increasing amounts of UV irradiation. However, Brca ${ }^{-/-}$MMECs displayed a 3 -fold increase in sensitivity to UV irradiation relative to that of $\mathrm{BrCa1}^{+/+}$MMECs ( $\left.\mathrm{p}=0.029\right)$.

To further explore the GGR defect in $\mathrm{BrCa1}^{-1-}$ MMECs, we investigated whether loss of Brcal may affect the expression of NER genes. We and others have shown that BRCA1 regulates the expression of human $D D B 2$ and $X P C[13,35]$, and the products of these genes are required for efficient GGR of CPDs in human cells [36].
Therefore, we evaluated the expression of $D d b 2$ and $X p c$ in $\mathrm{BrCal}^{+/+}$and $\mathrm{BrCal}^{-/-}$MMECs by RT-qPCR under the same conditions as those used for the GGR assay. When compared to $\mathrm{BrCa1}^{+/+}$MMECs, Brca1 ${ }^{-/-}$MMECs showed a statistically significant decrease in UV-induced expression of Xpc mRNA ( $\mathrm{p}=0.04$ ) but not of Ddb2 mRNA ( $\mathrm{p}$ $=0.8$ ) (Figure $4 \mathrm{c}$ and data not shown).

We next examined the effect of loss of Brcal on druginduced expression of Xpc. Following treatment with untreated control, $0.1 \mu \mathrm{M}$ cisplatin, or $0.01 \mu \mathrm{M}$ gemcitabine for 24 hours, we analyzed levels of $X p c$ mRNA by RT-qPCR in $\mathrm{Brcal}^{+/+}$and Brca1 ${ }^{-/-}$MMECs. Brca1 ${ }^{-/-}$ MMECs showed significantly less induction of Xpc mRNA following cisplatin treatment compared to $\mathrm{Brcal}^{+/+}$ MMECs ( $\mathrm{p}=0.009$; Figure 4d), whereas both $\mathrm{Brcal}^{+/+}$ and $\mathrm{Brca}^{-1-}$ MMECs showed no significant increase in $X p c$ mRNA expression following treatment with gemcitabine ( $p=0.6$; Figure $4 d$ ). Taken together, these data suggest that the increase in sensitivity to platinum agents observed due to the loss of Brcal expression may be attributed in part to an attenuation of transcriptional regulation of $X p c$, a DNA damage recognition gene, and a subsequent decrease in GGR function of the NER pathway.

\section{Effect of Loss of Brca1 on DNA Double-strand break repair}

Finally, due to the well-established role for BRCA1 in DNA double-strand break repair, we examined the effect of loss of Brca1 on levels of DNA strand breaks following treatment with certain drugs. $\mathrm{BrCal}^{+/+}$and $\mathrm{BrCal}^{-/-}$ 
a

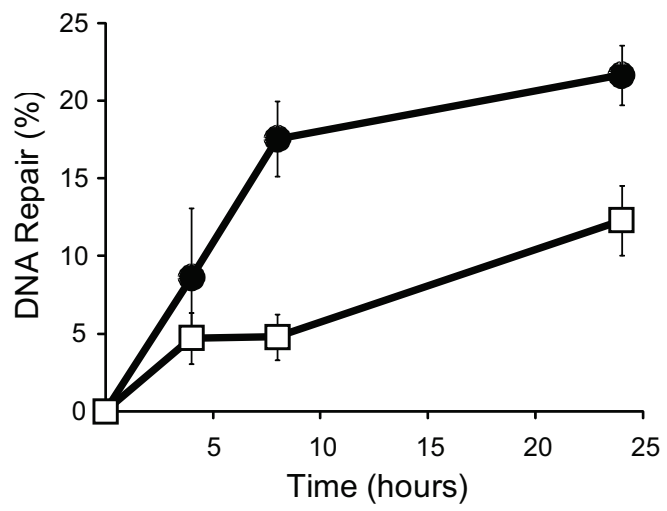

C

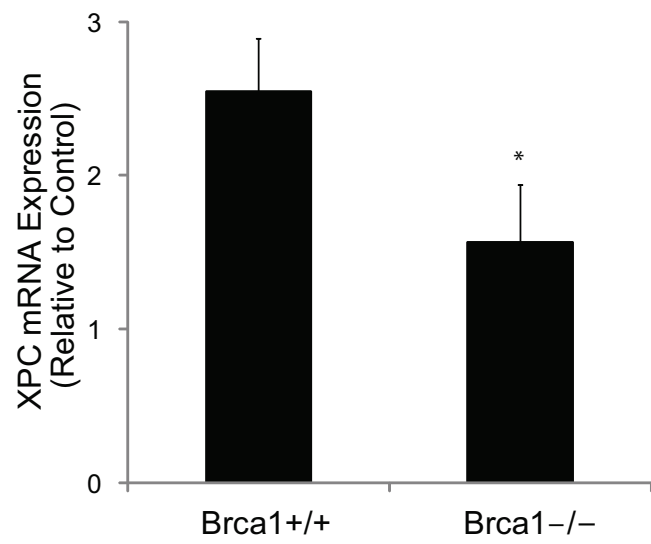

e

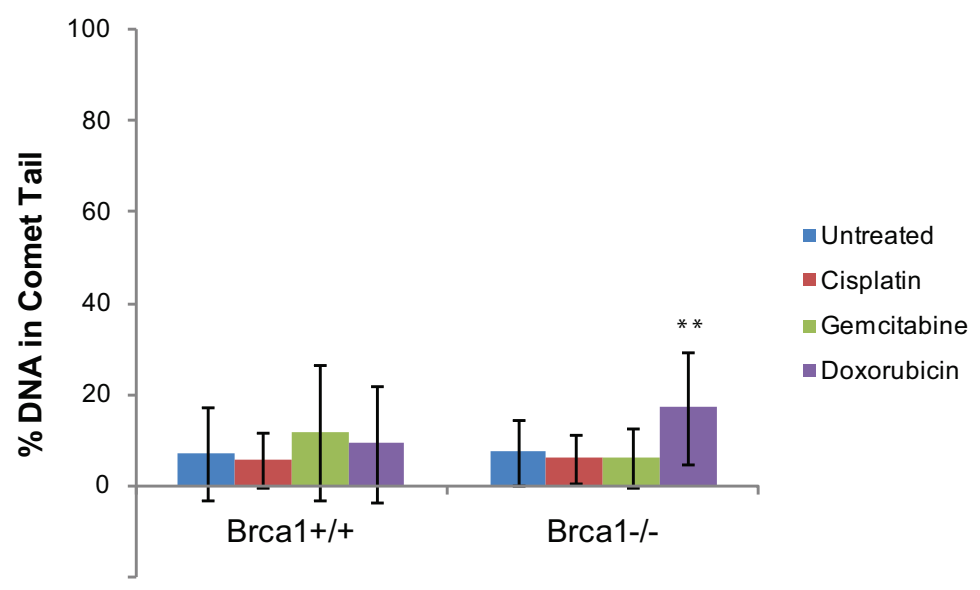

b

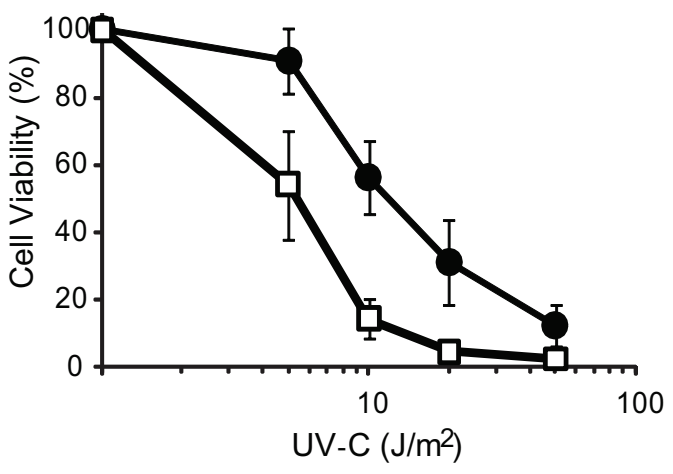

d

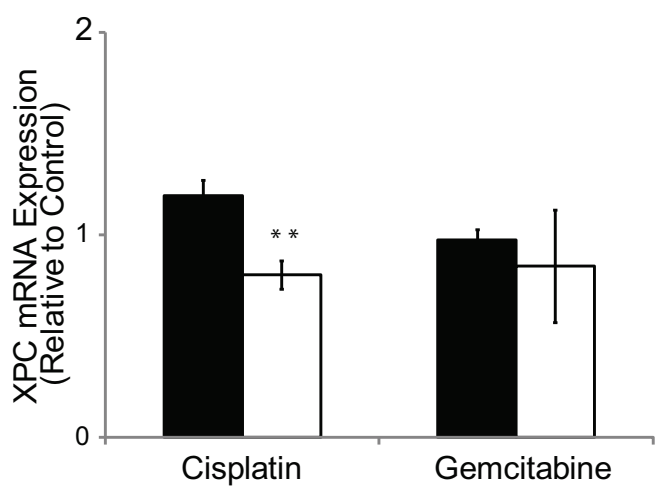

Figure 4 Effect of Brca1-deficiency on NER and Double-strand DNA Break Repair. In (a), GGR of CPDs in Brca1 ${ }^{+/+}$(black circle) and Brca ${ }^{-/}$ (white square) cells was measured using an immunoslot blot assay. Cells were exposed to $10 \mathrm{~J} / \mathrm{m}^{2}$ UV-irradiation and collected at the indicated times. DNA repair was expressed as a percentage relative to control. Data from triplicate DNA samples from three different biological experiments were expressed as an average \pm S.E.M. In (b), sensitivity to UV-irradiation was determined by MTT assay for Brca ${ }^{+/+}$(black circle) and $\mathrm{Brcal}^{-1-}$ (white square) cells. In (c), damage-induced expression of Xpc mRNA, an NER gene involved in DNA damage recognition, in Brcal ${ }^{+/+}$ and $\mathrm{BrCa}^{-/-}$cells was measured using RT-qPCR. Brcal ${ }^{+/+}$and Brcal ${ }^{-/}$cells were exposed to $10 \mathrm{~J} / \mathrm{m}^{2}$ of UV and either harvested immediately (control) or incubated in media and harvested $24 \mathrm{~h}$ later. In (d), expression of Xpc mRNA following 24 hours of treatment with $0.1 \mu \mathrm{M}$ cisplatin or $0.01 \mu \mathrm{M}$ gemcitabine in $\mathrm{BrCa}^{+/+}$and $\mathrm{Brca}^{-1-}$ cells was measured using RT-qPCR. Data were calculated relative to the untreated control and expressed as the average of three experiments \pm S.E.M. In (e), DNA strand breaks were measured at 24 hours following treatment with $0.1 \mu M$ cisplatin, $0.01 \mu \mathrm{M}$ gemcitabine, or $0.1 \mu \mathrm{M}$ doxorubicin in $\mathrm{Brcal}^{+/+}$and $\mathrm{Brca}^{-1-}$ cells using the alkaline comet assay. Comet tails indicate DNA damage. Unless indicated otherwise, data were expressed as an average of triplicate readings \pm S.D. ${ }^{*}, p<0.01 ;{ }^{*}, p<0.05$. 
MMECs were left untreated (control) or treated with 0.1 $\mu \mathrm{M}$ cisplatin, $0.01 \mu \mathrm{M}$ gemcitabine, or $0.1 \mu \mathrm{M}$ doxorubicin, and then after 24 hours for repair, subjected to the alkaline comet assay (Figure 4e). We observed similar levels of DNA strand breaks following treatment with cisplatin or gemcitabine compared to control in both Brca1 ${ }^{+/+}(\mathrm{p}=0.5$ and $\mathrm{p}=0.08$, respectively) and Brca $^{-1-}$ MMECs ( $\mathrm{p}=0.4$ and $\mathrm{p}=0.6$, respectively). However, we found significantly greater levels of DNA strand breaks following treatment with doxorubicin compared to the untreated control in $\mathrm{Brcal}^{-1-}$ MMECs $(\mathrm{p}=0.0004)$, but not in $B r c a 1^{+/+}$MMECs $(\mathrm{p}=0.4)$.

\section{Discussion}

Loss of BRCA1 function plays a role in the development of a substantial number of breast cancers, including more than $50 \%$ of hereditary cases due to germline mutations [37] and up to $30 \%$ of sporadic cases through mechanisms of epigenetic silencing [4]. BRCA1-associated cancers are typically triple-negative in phenotype, correlate with a poor clinical outcome [38-41], and are in need of improved treatment options. BRCA1 functions in DNA damage response pathways, cell-cycle control, chromatin remodeling, transcription regulation, and various other cellular processes [42-45]. In this study, we evaluated the cellular sensitivity to drugs that are dependent and independent of DNA damage response pathways and analyzed the corresponding DNA repair status in $\mathrm{BrCal}^{+/+}$and $\mathrm{BrCa1} \mathrm{I}^{-/-}$MMECs. We used an isogenic cellular system to allow the direct comparison of sensitivity to various drugs and found that among the drugs used in this study, cisplatin and gemcitabine produced the greatest therapeutic benefit to Brcal-deficient MMECs, and that when used in combination, produced a synergistic effect. This sensitivity may be attributed in part to defective NER, which is one of the DNA repair pathways normally responsible for repairing DNA adducts generated by cisplatin and is shown in this study to be defective in Brcal-deficient MMECs.

Loss of Brcal associates with sensitivity to platinumbased DNA-damaging agents. We found that the greatest therapeutic advantage to Brca1-deficient MMECs among the platinum agents to be with cisplatin, moreso than carboplatin or oxaliplatin. Brca1 ${ }^{-/-}$MMECs were 13-fold more sensitive to cisplatin than $\mathrm{BrCa1}^{+/+}$ MMECs (Figure 1b). While all platinum agents have the common ability to cross-link DNA, major differences occur in their mechanisms of action and resistance and in their stability (reviewed in [46-48]) that may explain the greater sensitivity to cisplatin compared to other members of the group. Consistent with our data, Sgagias et al. reported cisplatin sensitivity in these Brca1-deficient cells [23], and others have reported similar cisplatin sensitivity in other BRCA1-deficient cellular systems
[15-20,49]. Platinum agents induce DNA adducts and double-strand breaks that are typically repaired by NER and homologous recombination (HR), respectively [50]. Loss of BRCA1 is generally believed to associate with cisplatin sensitivity due to compromised HR, resulting in unrepairable DNA double strand breaks and subsequent cell death. Under our experimental conditions, we observed no difference in the levels of DNA strand breaks following cisplatin treatment in Brcal-wild-type versus null cells (Figure 4e). However, cells derived from the same Brcal mouse model as the MMECs that are described in this study have been shown to display genetic instability and sensitivity to agents that produce double-strand breaks [34], suggesting that these cells, like other BRCA1-deficient cells, display defective double-strand break repair. Therefore, the conditions for cisplatin treatment used in our experiments may have produced platinum -DNA adducts moreso than DNA double-strand breaks. We found that loss of Brca1 expression resulted in a defect in the GGR subpathway of NER. Specifically, we demonstrated that Brca1-deficient MMECs showed a reduced rate of GGR of CPDs (Figure 4a), significantly increased sensitivity to UV-irradiation (Figure 4b), and loss of $X p c$ transcriptional induction after DNA damage (Figure 4c). Similarly, Brca1-deficient MMECs exhibited sensitivity to platinum agents (Figure $1 \mathrm{~b}-\mathrm{d}$ ) and a loss of $X p c$ transcriptional induction after cisplatin treatment (Figure $4 d$ ). These data are consistent with human studies showing that overexpression of human BRCA1 enhances GGR through transcriptional regulation of NER genes, $X P C$, $D D B 2$, and GADD45 [13]. Therefore, loss of BRCA1 may also result in cisplatin sensitivity due to compromised NER. In support of this idea, both HR and NER have been described as mechanisms of resistance to cisplatin [50,51]. Furthermore, these same Brca1-deficient MMECs were more sensitive to inhibitors of PARP, a BER enzyme, and MMS, which produces lesions repaired by BER, and showed an aberrant response to oxidative stress that is consistent with a defect in BER $[12,23]$. Taken together, we propose that multiple repair pathways are likely to be responsible for BRCA1mediated sensitivity to platinum agents, including NER and HR.

In contrast to cisplatin, loss of Brcal did not affect sensitivity to the DNA-damaging agent doxorubicin. We found no difference in sensitivity between $\mathrm{Brcal}^{+/+}$and Brca1 $^{-/-}$MMECs (Figure 1a). Doxorubicin intercalates within DNA and inhibits topoisomerase II, resulting in DNA double-strand breaks. Given that the response to doxorubicin is dependent in part on HR for the repair of double-strand breaks and the response to platinum agents is dependent on both HR and NER, our finding that Brca1-deficient cells were defective in the GGR 
subpathway of NER may explain the difference in sensitivity between these two types of DNA damaging agents. Furthermore, the lack of effect on sensitivity to doxorubicin in Brca1-deficient MMECs may be attributed to the fact that topoisomerase II unwinds DNA for transcription, and we found that Brca1-deficient cells were proficient in TCR (data not shown). We observed greater levels of DNA strand breaks in $\mathrm{Brcal}^{-1-}$ MMECs compared to $\mathrm{BrCa1}^{+/+}$MMECs at 24 hours following doxorubicin treatment (Figure 4e). Therefore, the intercalating activity, which inhibits DNA replication and synthesis, may dominate over the topoisomerase II inhibiting activity of doxorubicin, and thus, eliminate the specificity for cell killing of Brca1-deficient cells. In support of this idea, Treszezamsky et al. found that due to compromised HR, BRCA1-deficent cells were sensitive to etoposide [52], which is a topoisomerase II poison but not a DNA intercalator. Therefore, both activities of doxorubicin may contribute to the comparable sensitivity for doxorubicin in $\mathrm{BrCa1}^{+/+}$and $\mathrm{BrCa1}^{-/-}$MMECs.

Loss of Brcal exhibits a variable response to antimetabolites. Brca1 ${ }^{-/-}$MMECs were 27-fold more sensitive to gemcitabine and 5-fold less sensitive to 5-FU than Brca1 +/+ MMECs. Interestingly, triple-negative breast cancers, which share a similar molecular and histopathological profile with BRCA1-mutated breast cancers, have also been found to be sensitive to gemcitabine $[49,53]$. Consistent with the mechanism of gemcitabine being independent of DNA repair, the increase in sensitivity to gemcitabine due to the loss of Brcal expression was not a result of defective NER (Figure $4 \mathrm{~d}$ ) or double-strand break repair (Figure 4e). However, gemcitabine has been shown to induce $\mathrm{H} 2 \mathrm{AX}$ phosphorylation and Rad51 nuclear foci formation, i.e. markers of DNA double strand breaks, at stalled replication forks in triple-negative breast cancer cells $[49,54]$. Therefore, it is possible that our experimental conditions for gemcitabine treatment did not produce significant double strand breaks. Both gemcitabine and 5-FU function as nucleoside analogs that inhibit DNA replication. However, gemcitabine also inhibits ribonucleotide reductase. This additional action of gemcitabine is likely to be responsible for the drastically different effects between the two drugs. For example, ribonucleotide reductase plays a role in maintaining the supply of dNTPS at sites of DNA damage to allow for efficient repair $[55,56]$. Gemcitabine-mediated inhibition of ribonucleotide reductase may preclude mechanisms of repair (other than NER or double-strand DNA break repair) from compensating in the absence of BRCA1-mediated DNA repair. Alternatively, functions other than DNA repair may determine gemcitabine sensitivity or 5-FU resistance in Brca1-deficient cells. These functions may be attributed to the RING-finger domain at the $\mathrm{N}$-terminus of $B R C A 1$ that functions in transcription regulation and/or the BRCT domain at the C-terminus of BRCA1 that functions in various processes through protein-protein interactions [43,44].

Loss of Brcal does not affect the sensitivity to taxanes. Current reports on the involvement of BRCA1 in determining sensitivity to this class of drug are conflicting $[41,57,58]$, and these data may be dependent on cell type or differences among model systems. Interestingly, a similar study using transformed $\mathrm{BrCa}^{+/+}$and $\mathrm{BrCa1}^{-/-}$ mouse ovarian epithelial cell lines also showed no difference in sensitivity to paclitaxel [59]. Regardless, further studies are warranted to determine the exact role that BRCA1 and related proteins play in paclitaxel sensitivity (or resistance).

Cisplatin and gemcitabine exert a drastic synergistic effect on cellular sensitivity in the absence of BRCA1. We found that both $B r c a 1^{+/+}$and $\mathrm{BrCa1}^{-/-}$MMECs showed synergy between the two drugs (Figure 3), and we and others have reported similar synergy in other cell types [49,53,60-63]. In fact, the cisplatin-gemcitabine combination is currently FDA-approved for use in the treatment of some non-small cell lung cancers. The relatively low concentrations that produced the individual drug sensitivities combined with the synergism in $\mathrm{BrCa}^{-1-}$ MMECs provides strong preclinical evidence for the cisplatin-gemcitabine combination in the treatment of BRCA1-associated breast cancers. While gemcitabine has not been shown to directly induce DNA damage (Figure 4e and [64]), nor has it shown dependency on DNA repair systems [65], it has been shown to inhibit repair of cisplatin-induced DNA damage [61,66,67], and this may contribute to the synergistic effect observed in Brca1-deficient cell lines. DNA repair is a mechanism of resistance to cisplatin [51]. Therefore, inhibition of repair, such as that due to gemcitabine, may produce sensitivity to cisplatin.

This study opens the door for the identification of other existing chemotherapeutic agents that may also be selectively sensitive to BRCA1-deficient cells. Other drugs may potentially be identified in a larger screen such as that described for BRCA2-deficient cells [68].

Due to the early success of PARP inhibitors, such as olaparib, in BRCA1-deficient tumors [10], it is possible that combination regimens including cisplatin and/or gemcitabine may be even more effective. In fact, we have recently initiated a Phase II clinical trial for gemcitabine, carboplatin and PARP inhibitor iniparib (BSI201) in the neoadjuvant treatment of BRCA1 or BRCA2 mutated and triple-negative breast cancer.

Clinical evidence is emerging that BRCA1- associated breast cancers are particularly sensitive to platinum agents. A recent study using registry data from Poland identified 102 women who carried a BRCA1 founder mutation and had undergone neoadjuvant chemotherapy for breast 
cancer [69]. Remarkably, 83\% (10 of 12) of those treated with cisplatin achieved a pathological complete response, compared to more typical rates of $22 \%$ with doxorubicin, cyclophosphamide and 5-FU based regimens. A report from the Dana-Farber Cancer Institute documented a 22\% pathological complete response with single-agent cisplatin in the neoadjuvant setting for 28 women with early stage triple-negative breast cancer; only 2 patients were known BRCA1 mutation carriers, though both achieved a complete response [70]. At this point, nothing is known regarding gemcitabine as a selective targeted agent in BRCA1 mutant breast cancers.

\section{Conclusions}

Doxorubicin, 5-FU, paclitaxel, and docetaxel are all currently used in breast cancer therapy. On the other hand, cisplatin and gemcitabine are not included in first line regimens for breast cancer, yet we found that they show therapeutic effectiveness in Brca1-deficient MMECs. Taken together, our data suggest a novel targeted approach to treating $B R C A 1$-mutated or other DNA repair-deficient breast cancers to include gemcitabine and cisplatin. Based upon these results, clinical trials have been initiated to examine the role of platinum drugs with gemcitabine in BRCA1- mutant and triplenegative breast cancers [71].

\section{List of Abbreviations}

6-4PP: 6-4 photoproduct; BER: base-excision repair; CPD: cyclobutane pyrimidine dimer; dNTPs: deoxyribonucleotides; GGR: global genomic repair; HR: homologous recombination; MMECs: murine mammary epithelial cells; MTT: 3-(4,5-dimethylthiazol-2-yl)-2,5-diphenyltetrazolium bromide; NER: nucleotide-excision repair; RT-qPCR: real-time reverse-transcriptase polymerase chain reaction; TCR: transcription-coupled repair; UV: ultraviolet.

\section{Acknowledgements}

We thank Kenneth H. Cowan and Magdalene K. Sgasias (Eppley Institute for Research in Cancer and Allied Diseases, University of Nebraska Medical Center) for the $\mathrm{Brcal}^{+/+}$and $\mathrm{BrCa}^{-/-}$MMECs and Toshio Mori (Nara Medical University, Japan) for the monoclonal antibodies specific for CPDs and 64PPs and R. Stephen Lloyd (Oregon Health Sciences University) for bacteriophage T4 endonuclease V. We also thank Stephanie J. Turner for technical assistance. E.A. was supported by the Susan G. Komen Postdoctoral Fellowship Award KG080695. V.B.S. and A.R.H. were supported by ASCO Young Investigator Awards and a Postdoctoral Fellowship from The California Breast Cancer Research Program. P.S.L. was supported by National Institutes of Health-National Research Service Award PHS NRSA 5 T32 CA09302-27 and American Cancer Society Postdoctoral Fellowship Award PF-06-037-01-GMC. J.M.F. was supported by the National Institutes of Health Award RO1 CA83889 and the Breast Cancer Research Foundation.

\section{Author details}

${ }^{1}$ Department of Medicine, Division of Oncology, Stanford University School of Medicine, Center for Clinical Sciences Research, Stanford, CA 94305, USA ${ }^{2}$ Department of Genetics, Stanford University School of Medicine, Stanford, CA 94305, USA.

\section{Authors' contributions}

EA constructed the manuscript, carried out the analysis and interpretation of data, and generated the DNA strand break data. VBS participated in the design of the study and acquired the chemosensitivity data. ARH conducted the NER experiments. PSL and LM analyzed damage-induced expression of
GGR genes. JMF conceived and supervised the study. All authors have read and approved the final manuscript.

Received: 12 January 2011 Accepted: 19 July 2011

Published: 19 July 2011

\section{References}

1. Antoniou A, Pharoah PD, Narod S, Risch HA, Eyfjord JE, Hopper JL, Loman N, Olsson H, Johannsson O, Borg A, et al: Average risks of breast and ovarian cancer associated with BRCA1 or BRCA2 mutations detected in case Series unselected for family history: a combined analysis of 22 studies. Am J Hum Genet 2003, 72(5):1117-1130.

2. Birgisdottir V, Stefansson OA, Bodvarsdottir SK, Hilmarsdottir H, Jonasson JG, Eyfjord JE: Epigenetic silencing and deletion of the BRCA1 gene in sporadic breast cancer. Breast Cancer Res 2006, 8(4):R38.

3. Butcher DT, Rodenhiser DI: Epigenetic inactivation of BRCA1 is associated with aberrant expression of CTCF and DNA methyltransferase (DNMT3B) in some sporadic breast tumours. European journal of cancer 2007, 43(1):210-219.

4. Catteau A, Morris JR: BRCA1 methylation: a significant role in tumour development? Semin Cancer Biol 2002, 12(5):359-371.

5. Miyamoto K, Fukutomi T, Asada K, Wakazono K, Tsuda H, Asahara T, Sugimura T, Ushijima T: Promoter hypermethylation and posttranscriptional mechanisms for reduced BRCA1 immunoreactivity in sporadic human breast cancers. Jpn J Clin Oncol 2002, 32(3):79-84.

6. Rice JC, Futscher BW: Transcriptional repression of BRCA1 by aberrant cytosine methylation, histone hypoacetylation and chromatin condensation of the BRCA1 promoter. Nucleic acids research 2000, 28(17):3233-3239.

7. Wilson CA, Ramos L, Villasenor MR, Anders KH, Press MF, Clarke K, Karlan B, Chen JJ, Scully R, Livingston D, et al: Localization of human BRCA1 and its loss in high-grade, non-inherited breast carcinomas. Nature genetics 1999, 21(2):236-240.

8. Lakhani SR, Van De Vijver MJ, Jacquemier J, Anderson TJ, Osin PP, McGuffog L, Easton DF: The pathology of familial breast cancer: predictive value of immunohistochemical markers estrogen receptor, progesterone receptor, HER-2, and p53 in patients with mutations in BRCA1 and BRCA2. J Clin Oncol 2002, 20(9):2310-2318.

9. Palacios J, Honrado E, Osorio A, Cazorla A, Sarrio D, Barroso A, Rodriguez S, Cigudosa JC, Diez O, Alonso C, et al: Phenotypic characterization of BRCA1 and BRCA2 tumors based in a tissue microarray study with 37 immunohistochemical markers. Breast Cancer Res Treat 2005, 90(1):5-14.

10. Tutt A, Robson M, Garber JE, Domchek SM, Audeh MW, Weitzel JN, Friedlander M, Arun B, Loman N, Schmutzler RK, et al: Oral poly(ADPribose) polymerase inhibitor olaparib in patients with BRCA1 or BRCA2 mutations and advanced breast cancer: a proof-of-concept trial. Lancet 2010, 376(9737):235-244

11. Zhang J, Powell SN: The role of the BRCA1 tumor suppressor in DNA double-strand break repair. Mol Cancer Res 2005, 3(10):531-539.

12. Alli E, Sharma VB, Sunderesakumar P, Ford JM: Defective repair of oxidative dna damage in triple-negative breast cancer confers sensitivity to inhibition of poly(ADP-ribose) polymerase. Cancer Res 2009, 69(8):3589-3596

13. Hartman AR, Ford JM: BRCA1 induces DNA damage recognition factors and enhances nucleotide excision repair. Nat Genet 2002, 32(1):180-184.

14. Hartman AR, Ford JM: BRCA1 and p53: compensatory roles in DNA repair. J Mol Med 2003, 81(11):700-707.

15. Bhattacharyya A, Ear US, Koller BH, Weichselbaum RR, Bishop DK: The breast cancer susceptibility gene BRCA1 is required for subnuclear assembly of Rad51 and survival following treatment with the DNA cross-linking agent cisplatin. J Biol Chem 2000, 275(31):23899-23903.

16. Cass I, Baldwin RL, Varkey T, Moslehi R, Narod SA, Karlan BY: Improved survival in women with BRCA-associated ovarian carcinoma. Cancer 2003, 97(9):2187-2195.

17. Husain $A$, He G, Venkatraman ES, Spriggs DR: BRCA1 up-regulation is associated with repair-mediated resistance to cisdiamminedichloroplatinum(II). Cancer Res 1998, 58(6):1120-1123.

18. Quinn JE, Kennedy RD, Mullan PB, Gilmore PM, Carty M, Johnston PG, Harkin DP: BRCA1 functions as a differential modulator of chemotherapyinduced apoptosis. Cancer Res 2003, 63(19):6221-6228. 
19. Sylvain V, Lafarge S, Bignon YJ: Dominant-negative activity of a Brca1 truncation mutant: effects on proliferation, tumorigenicity in vivo, and chemosensitivity in a mouse ovarian cancer cell line. Int J Oncol 2002, 20(4):845-853.

20. Tassone P, Tagliaferri P, Perricelli A, Blotta S, Quaresima B, Martelli ML, Goel A, Barbieri V, Costanzo F, Boland CR, et al: BRCA1 expression modulates chemosensitivity of BRCA1-defective HCC1937 human breast cancer cells. Br J Cancer 2003, 88(8):1285-1291.

21. Bryant HE, Schultz N, Thomas HD, Parker KM, Flower D, Lopez E, Kyle S, Meuth M, Curtin NJ, Helleday T: Specific killing of BRCA2-deficient tumours with inhibitors of poly(ADP-ribose) polymerase. Nature 2005, 434(7035):913-917.

22. Farmer H, McCabe N, Lord CJ, Tutt AN, Johnson DA, Richardson TB, Santarosa M, Dillon KJ, Hickson I, Knights C, et al: Targeting the DNA repair defect in BRCA mutant cells as a therapeutic strategy. Nature 2005, 434(7035):917-921.

23. Sgagias MK, Wagner KU, Hamik B, Stoeger S, Spieker R, Huber LJ, Chodosh LA, Cowan KH: Brca1-deficient murine mammary epithelial cells have increased sensitivity to CDDP and MMS. Cell Cycle 2004, 3(11):1451-1456.

24. Xu X, Wagner KU, Larson D, Weaver Z, Li C, Ried T, Hennighausen L, Wynshaw-Boris A, Deng CX: Conditional mutation of Brca1 in mammary epithelial cells results in blunted ductal morphogenesis and tumour formation. Nat Genet 1999, 22(1):37-43.

25. Lin PS, MCPherson LA, Chen AY, Sage J, Ford JM: The role of the retinoblastoma/E2F1 tumor suppressor pathway in the lesion recognition step of nucleotide excision repair. DNA Repair (Amst) 2009, 8(7):795-802.

26. Fitch ME, Cross IV, Turner SJ, Adimoolam S, Lin CX, Williams KG, Ford JM: The DDB2 nucleotide excision repair gene product p48 enhances global genomic repair in $\mathrm{p} 53$ deficient human fibroblasts. DNA Repair (Amst) 2003, 2(7):819-826.

27. Ford JM, Hanawalt PC: Li-Fraumeni syndrome fibroblasts homozygous for p53 mutations are deficient in global DNA repair but exhibit normal transcription-coupled repair and enhanced UV resistance. Proc Natl Acad Sci USA 1995, 92(19):8876-8880.

28. Smith ML, Ford JM, Hollander MC, Bortnick RA, Amundson SA, Seo YR, Deng CX, Hanawalt PC, Fornace AJ Jr: p53-mediated DNA repair responses to UV radiation: studies of mouse cells lacking p53, p21, and/ or gadd45 genes. Mol Cell Biol 2000, 20(10):3705-3714.

29. Tallarida RJ: Drug synergism: its detection and applications. J Pharmacol Exp Ther 2001, 298(3):865-872.

30. Chou TC, Talalay P: Quantitative analysis of dose-effect relationships: the combined effects of multiple drugs or enzyme inhibitors. Adv Enzyme Regul 1984, 22:27-55.

31. Singh NP, McCoy MT, Tice RR, Schneider EL: A simple technique for quantitation of low levels of DNA damage in individual cells. Exp Cell Res 1988, 175(1):184-191.

32. Crook T, Brooks LA, Crossland S, Osin P, Barker KT, Waller J, Philp E, Smith PD, Yulug I, Peto J, et al: p53 mutation with frequent novel condons but not a mutator phenotype in BRCA1- and BRCA2-associated breast tumours. Oncogene 1998, 17(13):1681-1689.

33. Schuyer M, Berns EM: Is TP53 dysfunction required for BRCA1-associated carcinogenesis? Mol Cell Endocrinol 1999, 155(1-2):143-152.

34. XU X, Weaver Z, Linke SP, Li C, Gotay J, Wang XW, Harris CC, Ried T, Deng CX: Centrosome amplification and a defective G2-M cell cycle checkpoint induce genetic instability in BRCA1 exon 11 isoformdeficient cells. Mol Cell 1999, 3(3):389-395.

35. Takimoto R, MacLachlan TK, Dicker DT, Niitsu Y, Mori T, el-Deiry WS: BRCA transcriptionally regulates damaged DNA binding protein (DDB2) in the DNA repair response following UV-irradiation. Cancer Biol Ther 2002, 1(2):177-186.

36. Wood RD, Mitchell M, Sgouros J, Lindahl T: Human DNA repair genes. Science 2001, 291(5507):1284-1289.

37. Lux MP, Fasching PA, Beckmann MW: Hereditary breast and ovarian cancer: review and future perspectives. J Mol Med 2006, 84(1):16-28.

38. Seery LT, Knowlden JM, Gee JM, Robertson JF, Kenny FS, Ellis IO, Nicholson Rl: BRCA1 expression levels predict distant metastasis of sporadic breast cancers. Int J Cancer 1999, 84(3):258-262.

39. Chappuis PO, Kapusta L, Begin LR, Wong N, Brunet JS, Narod SA, Slingerland J, Foulkes WD: Germline BRCA1/2 mutations and p27(Kip1) protein levels independently predict outcome after breast cancer. J Clin Oncol 2000, 18(24):4045-4052.

40. Stoppa-Lyonnet D, Ansquer Y, Dreyfus H, Gautier C, Gauthier-Villars M, Bourstyn E, Clough KB, Magdelenat H, Pouillart P, Vincent-Salomon A, et al: Familial invasive breast cancers: worse outcome related to BRCA1 mutations. J Clin Oncol 2000, 18(24):4053-4059.

41. Foulkes WD: BRCA1 and BRCA2: chemosensitivity, treatment outcomes and prognosis. Fam Cancer 2006, 5(2):135-142.

42. Narod SA, Foulkes WD: BRCA1 and BRCA2: 1994 and beyond. Nat Rev Cancer 2004, 4(9):665-676.

43. Boulton SJ: Cellular functions of the BRCA tumour-suppressor proteins. Biochem Soc Trans 2006, 34(Pt 5):633-645.

44. Huen MS, Sy SM, Chen J: BRCA1 and its toolbox for the maintenance of genome integrity. Nat Rev Mol Cell Biol 2010, 11(2):138-148.

45. Gramatges MM, Telli ML, Balise R, Ford JM: Longer relative telomere length in blood from women with sporadic and familial breast cancer compared with healthy controls. Cancer Epidemiol Biomarkers Prev 2010, 19(2):605-613.

46. Wang B, Matsuoka S, Ballif BA, Zhang D, Smogorzewska A, Gygi SP, Elledge SJ: Abraxas and RAP80 form a BRCA1 protein complex required for the DNA damage response. Science 2007, 316(5828):1194-1198.

47. Harper JW, Elledge SJ: The DNA damage response: ten years after. Mol Cell 2007, 28(5):739-745.

48. Wang B, Elledge SJ: Ubc13/Rnf8 ubiquitin ligases control foci formation of the Rap80/Abraxas/Brca1/Brcc36 complex in response to DNA damage. Proc Natl Acad Sci USA 2007, 104(52):20759-20763.

49. Hastak K, Alli E, Ford JM: Synergistic chemosensitivity of triple-negative breast cancer cell lines to poly(ADP-Ribose) polymerase inhibition, gemcitabine, and cisplatin. Cancer Res 2010, 70(20):7970-7980.

50. Kartalou M, Essigmann JM: Mechanisms of resistance to cisplatin. Mutat Res 2001, 478(1-2):23-43.

51. Crul M, Schellens JH, Beijnen JH, Maliepaard M: Cisplatin resistance and DNA repair. Cancer Treat Rev 1997, 23(5-6):341-366.

52. Treszezamsky AD, Kachnic LA, Feng Z, Zhang J, Tokadjian C, Powell SN: BRCA1- and BRCA2-deficient cells are sensitive to etoposide-induced DNA double-strand breaks via topoisomerase II. Cancer Res 2007, 67(15):7078-7081.

53. Koshy N, Quispe D, Shi R, Mansour R, Burton GV: Cisplatin-gemcitabine therapy in metastatic breast cancer: Improved outcome in triple negative breast cancer patients compared to non-triple negative patients. Breast 2010, 19(3):246-248.

54. Ewald B, Sampath D, Plunkett W: H2AX phosphorylation marks gemcitabine-induced stalled replication forks and their collapse upon Sphase checkpoint abrogation. Mol Cancer Ther 2007, 6(4):1239-1248.

55. Hakansson P, Hofer A, Thelander L: Regulation of mammalian ribonucleotide reduction and dNTP pools after DNA damage and in resting cells. J Biol Chem 2006, 281(12):7834-7841.

56. Niida H, Katsuno Y, Sengoku M, Shimada M, Yukawa M, Ikura M, Ikura T, Kohno K, Shima H, Suzuki $H$, et al: Essential role of Tip60-dependent recruitment of ribonucleotide reductase at DNA damage sites in DNA repair during G1 phase. Genes Dev 2010, 24(4):333-338.

57. De Ligio JT, Velkova A, Zorio DA, Monteiro AN: Can the status of the breast and ovarian cancer susceptibility gene 1 product (BRCA1) predict response to taxane-based cancer therapy? Anticancer Agents Med Chem 2009, 9(5):543-549.

58. Kennedy RD, Quinn JE, Mullan PB, Johnston PG, Harkin DP: The role of BRCA1 in the cellular response to chemotherapy. J Natl Cancer Inst 2004, 96(22):1659-1668.

59. Xing D, Orsulic S: A mouse model for the molecular characterization of brca1-associated ovarian carcinoma. Cancer Res 2006, 66(18):8949-8953.

60. Bergman AM, Ruiz van Haperen WW, Veerman G, Kuiper CM, Peters GJ: Synergistic interaction between cisplatin and gemcitabine in vitro. Clin Cancer Res 1996, 2(3):521-530.

61. Moufarij MA, Phillips DR, Cullinane C: Gemcitabine potentiates cisplatin cytotoxicity and inhibits repair of cisplatin-DNA damage in ovarian cancer cell lines. Mol Pharmacol 2003, 63(4):862-869.

62. Theodossiou C, Cook JA, Fisher J, Teague D, Liebmann JE, Russo A, Mitchell JB: Interaction of gemcitabine with paclitaxel and cisplatin in human tumor cell lines. Int J Oncol 1998, 12(4):825-832.

63. van Moorsel CJ, Pinedo HM, Veerman G, Bergman AM, Kuiper CM, Vermorken JB, van der Vijgh WJ, Peters GJ: Mechanisms of synergism 
between cisplatin and gemcitabine in ovarian and non-small-cell lung cancer cell lines. Br J Cancer 1999, 80(7):981-990.

64. Unger FT, Klasen HA, Tchartchian G, de Wilde RL, Witte I: DNA damage induced by cis- and carboplatin as indicator for in vitro sensitivity of ovarian carcinoma cells. BMC Cancer 2009, 9:359.

65. Crul M, van Waardenburg RC, Bocxe S, van Eijndhoven MA, Pluim D, Beijnen JH, Schellens JH: DNA repair mechanisms involved in gemcitabine cytotoxicity and in the interaction between gemcitabine and cisplatin. Biochem Pharmacol 2003, 65(2):275-282.

66. Peters GJ, Van Moorsel CJ, Lakerveld B, Smid K, Noordhuis P, Comijn EC, Weaver D, Willey JC, Voorn D, Van der Vijgh WJ, et al: Effects of gemcitabine on cis-platinum-DNA adduct formation and repair in a panel of gemcitabine and cisplatin-sensitive or -resistant human ovarian cancer cell lines. Int J Oncol 2006, 28(1):237-244.

67. Yang $L Y$, Li L, Jiang $H$, Shen $Y$, Plunkett W: Expression of ERCC1 antisense RNA abrogates gemicitabine-mediated cytotoxic synergism with cisplatin in human colon tumor cells defective in mismatch repair but proficient in nucleotide excision repair. Clin Cancer Res 2000, 6(3):773-781.

68. Evers B, Schut E, van der Burg E, Braumuller TM, Egan DA, Holstege H, Edser P, Adams DJ, Wade-Martins R, Bouwman P, et al: A high-throughput pharmaceutical screen identifies compounds with specific toxicity against BRCA2-deficient tumors. Clinical cancer research : an official journal of the American Association for Cancer Research 2010, 16(1):99-108.

69. Byrski T, Gronwald J, Huzarski T, Grzybowska E, Budryk M, Stawicka M, Mierzwa T, Szwiec M, Wisniowski R, Siolek M, et al: Pathologic complete response rates in young women with BRCA1-positive breast cancers after neoadjuvant chemotherapy. J Clin Oncol 2010, 28(3):375-379.

70. Silver DP, Richardson AL, Eklund AC, Wang ZC, Szallasi Z, Li Q, Juul N, Leong CO, Calogrias D, Buraimoh A, et al: Efficacy of neoadjuvant Cisplatin in triple-negative breast cancer. J Clin Oncol 2010, 28(7):1145-1153.

71. Telli ML, Ford JM: Novel treatment approaches for triple-negative breast cancer. Clin Breast Cancer 2010, 10(Suppl 1):E16-22.

doi:10.1186/1471-2210-11-7

Cite this article as: Alli et al:: Enhanced sensitivity to cisplatin and gemcitabine in Brca1-deficient murine mammary epithelial cells. BMC Pharmacology 2011 11:7.

\section{Submit your next manuscript to BioMed Central and take full advantage of:}

- Convenient online submission

- Thorough peer review

- No space constraints or color figure charges

- Immediate publication on acceptance

- Inclusion in PubMed, CAS, Scopus and Google Scholar

- Research which is freely available for redistribution

Submit your manuscript at www.biomedcentral.com/submit
Biomed Central 